АСОНОВ Николай Васильевич - доктор политических наук, профессор кафедры политологии Московского педагогического государственного университета (119991, Россия, г. Москва, ул. М. Пироговская, 1, cmp. 1; nbassonov@yandex.ru)

\title{
ПРОБЛЕМА СООТВЕТСТВИЯ ПРАВОСЛАВНОЙ ЦЕРКВИ ГРАЖДАНСКОМУ ОБЩЕСТВУ
}

\begin{abstract}
Аннотация. В статье опровергается популярная сегодня точка зрения на Русскую православную церковь как на один из институтов гражданского общества и доказывается их полная противоположность, раскрывающаяся через отношение к власти и к структурным элементам политической системы (культурноидеологической, нормативной и институциональной).
\end{abstract}

Ключевые слова: Русская православная церковь, власть, ценности, гражданское общество, правовое государство, либерализм

@ момента внедрения в российский научный оборот понятия «гражданское общество» в конце 80-х гг. XX в. стала замечаться серьезная путаница в его осмыслении, когда Церковь стала трактоваться как институт гражданского общества. Но причину этой путаницы следует искать не в России. Ее корни лежат в западной либеральной среде. Теоретики либерализма, выросшего на почве Ренессанса и протестантизма как отрицания средневековых представлений о мире и человеке, понимали, что осуществить свое стремление к мировому господству можно только с опорой на идеологию универсальных ценностей как отказ от всех ранее существующих всеобщих ценностей и целей. Такая идеология не должна быть «привязана» ни к одной религии мира или какому-либо цивилизационному полюсу. В то же время она не могла родиться на пустом месте, и потому ей приходилось использовать наработки предшествующих мыслителей, перекраивая их на свой лад.

В сущности, народу предлагалась новая религия, но только светского типа, одной из важнейших особенностей которой стало учение хилиазма, которое было принято в иудаизме и через Ветхий Завет перешло в Апокалипсис. Оно получило широкую популярность у христиан со II по V в., но потом было отвергнуто ими как лжеучение ${ }^{1}$. Общий смысл хилиазма сводился к вере в то, что на Земле будет установлено общество социальной гармонии (Тысячелетнее царство праведников), когда людям откроются все тайны Земли и Господь воззовет прошлое 2 .

Между тем, если православная церковь рассматривает Тысячелетнее царство как «Божественный конец Земли и ее завершение» [Кирьянов 2001: 196], то светская трактовка хилиазма, вписанная в теорию гражданского общества, носит совсем иной характер. Она без всяких научных доводов игнорирует альтернативные точки зрения, например, доказывающие, что новый тип общности будет представлять собой «глобальный человейник». Его строительство «только начинается», «но, похоже на то, что это будет история, которая по своей трагичности намного превзойдет все трагедии прошлого» [Зиновьев 2007: 507].

Взамен этого выдвигается жизнеутверждающий принцип «бесконечности

1 Полный церковно-славянский словарь в 2 т. (сост. священник магистр Г. Дьяченко). М.: ТЕРРА-Книжный клуб. Т. 2. 1998. С. 785.

2 Екклесиаст: 3, 15. 
вечного совершенствования... общества, власти, политики и человека» 1 . При этом мы нигде в рамках теории гражданского общества не найдем доказательных аргументов его вечного улучшения, кстати, полностью игнорирующего все объективные законы бытия. А они требуют учитывать движение всего, что когда-либо возникло, к своей отрицательной противоположности (вырождению) и неизбежной гибели, когда иссякнут все ресурсы жизнедеятельности.

В основу данной теории положена вера в человека, точнее сказать, в постоянное самосовершенствование живой материи, которое якобы заложено в ее природе. На этой вере либерализм создал концепцию примата индивида (личности) и присущих ему с рождения социально-политических прав и свобод как высшей ценности. Поэтому он главную цель власти видит в защите индивида и того, что ему принадлежит как свободной личности. А эффективно осуществить это может только гражданское общество в союзе с правовым государством.

Между тем, для православия высшей ценностью является душа человека. Следовательно, главной целью власти должно стать спасение души для Царствия Небесного. Но т.к. наш мир «лежит во зле», верить в его поступательное движение, расширяя социально-политические права и свободы граждан, нельзя. Ведь, согласно Иоанну Богослову, «все, что в мире: похоть плоти, похоть очей и гордость житейская, не есть от Отца» 2 . Растущее господство этих страстей надо сдерживать, устанавливая жесткие рамки поведения, но идеология гражданского общества мешает этому, требуя от церкви дальнейшего раскрепощения личности. Она не признает толкование Ипполитом Римским Книги пророка Даниила, указывающее на растущее в нас зло, способное вместо социального государства произвести на свет антихриста, «который и восстановит царство Иудейское» ${ }^{3}$.

При этом царстве ожидаемое социальное блаженство обернется своей отрицательной противоположностью, и сбудется пророческое предвидение апостола Павла, что «в последние дни наступят времена тяжкие. Ибо люди будут самолюбивы, сребролюбивы, горды, надменны, злоречивы... жестоки, не любящие добра, предатели... имеющие вид благочестия». Народ нравственно оскудеет настолько, что «здравого учения принимать не будет, но по своим прихотям будет избирать себе учителей, которые бы льстили слуху» ${ }^{4}$. Такая позиция полностью противоречит прогностическим установкам гражданского общества и совсем не вписывается в концепцию правового государства. Уже на одном только этом основании можно говорить не о союзе, а об антагонизме, присутствующем в культурно-идеологической подсистеме этих двух обществ.

Означенный антагонизм сквозит и в понимании социального идеала, к которому надо стремиться. Одной из важнейших специфик человека и общества, выделенных православной церковью, является развитая в нас греховность, порождающая растущую тягу к материальным благам и стирающая разницу между свободой для греха и от греха. И если ценностно-целевая установка гражданского общества игнорирует это положение, признавая безгрешную природу человека, предпочитая делать ставку на дух предпринимательства как норму социальных отношений, обеспечивающих прогресс, то Церковь с этим категорически не согласна. Для нее борьба с греховностью видится главным

\footnotetext{
1 Политология: энциклопедический словарь (общ. ред. и сост. Ю.И. Аверьянов). М.: Издво Московского коммерческого университета. 1993. С. 75.

2 Первое соборное послание святого апостола Иоанна Богослова. Гл. 2:16.

3 Ипполит Римский. О Христе и Антихристе. - Уиение об Антихристе в древности и средневековье (сост. Б.Г. Деревенский). СПб: Алетейя. 2000. С. 213.

4 Новый Завет. Апостол Павел. Второе послание к Тимофею. Гл. 3 (1-5); Гл. 4 (3).
} 
импульсом жизни, включающим в себя молитвенный тон раскаяния, требующий от граждан покаяния и возвращения, как писал Иоанн Дамаскин, «от того, что противно природе, к тому, что согласно с природою... происходящему при помощи подвижнической жизни» [Дамаскин 2000: 116].

Смирение и борьба с внутренними недостатками, заставляющими тяготеть к материальным прелестям жизни и уводящим от нравственного совершенства, понимаются как важная ценностно-целевая установка. «Добровольно нищие по велению своего Духа», «плачущие», «кроткие», «милостивые», «чистые сердцем» и «миротворцы» воспринимаются как «соль земли» и «свет мира» сего. На этом строятся этические требования, призывающие не гневаться, мириться с соперником и любить врагов своих, не собирать сокровищ и творить добро тайно, довольствоваться тем, что имеем, не заботясь о том, что есть и пить, но искать прежде всего Царствия Небесного.

Тут стоит отметить, что доктрина не гражданского общества, а Русской православной церкви отказывается рассматривать действующую у нас институциональную и нормативно-правовую подсистемы как воплощение нравственных начал истинной веры. Глава «Церковь и государство» дает нам понять, что, хотя правовой суверенитет принадлежит государственной власти, она вторична по отношению к духовной, ибо только Церковь является богоустановленной реальностью. Значит, светская власть в лице правового государства и гражданского общества не должна себя абсолютизировать. Тем самым косвенно указывается на то, что действующая система управления противоречит православному пониманию государства, власти и общества.

Кроме того, явную угрозу интересам Кремля и гражданского общества несет принципиальное положение, согласно которому, видя «нарушения обществом или государством установлений и заповедей Божиих», православный человек может занять «позицию мирного гражданского неповиновения». Ведь с точки зрения авторов данной доктрины, изложенной в III.7, «современные демократии, в том числе монархические по форме, не ищут божественной санкции власти» 1 , следовательно, они не даны, а попущены Богом как одна из форм политического зла. Подобное положение содержится и в учебнике церковного права [Цыпин 2002: 633]. Стало быть, церковное общество, ориентированное на принцип соборности как положительную альтернативу парламентаризму и разделению властей, в структуру которых вписано гражданское общество, опять выпадает из светских рамок действующей у нас институциональной модели либерального управления, которую власть менять категорически не желает. А если к этому добавить еще и нормативную базу, содержащуюся в Афинской синтагме, практически полностью противоречащую пятой Конституции и ее поправкам от 2020 г., тогда вообще отпадает всякое сомнение в несоответствии православной церкви гражданскому обществу не только в теории, но и в практике.

Не удивительно, что подобная доктрина вызвала у действующего президента сдержанное раздражение. Значит, надо говорить не просто о несоответствии православной церкви гражданскому обществу, а о скрытом конфликте между ними, в котором государственная власть постарается подавить Церковь, изменив ее доктрину в свою пользу и подчинив ее епископат своим интересам. Когда это случится, а случится это обязательно, официальная Церковь утратит свое православие и сольется с гражданским обществом, приняв его систему ценностей и целей. Ведь, отделив ее от государства, светская власть не только

1 Основы социальной концепции Русской Православной Церкви. Доступ: http://www. patriarchia.ru/db/text/419128.html (проверено 17.01.2022). 
показала свое несогласие с ней, но и лишила Церковь реального влияния на ресурсы и методы управления, почти целиком сосредоточив их в своих руках.

\section{Список литературы}

Дамаскин Иоанн. 2000. Точное изложение православной веры. М.: Лодья. 465 с. Зиновьев А.А. 2007. Запад. М.: Алгоритм. 512 с.

Кирьянов Б.Н. (свящ.) 2001. Полное изложение истины о Тысячелетнем иарстве Господа на Земле. СПб: Алетейя. 302 с.

Цыпин В. (протоиерей). 2002. Курс церковного права. Клин: Фонд «Христианская жизнь». 704 с.

ASONOV Nikolai Vasi'evich, Dr.Sci. (Pol.Sci.), Professor of the Chair of Political Science, Moscow State Pedagogical University (bld. 1, 1 Malaya Pirogovskaya St, Moscow, Russia, 119991; nbassonov@yandex.ru)

\section{THE PROBLEM OF CONFORMITY OF THE ORTHODOX CHURCH WITH CIVIL SOCIETY}

Abstract. The article disproves the currently popular point of view on the Russian Orthodox Church as one of the institutions of civil society and shows their complete opposite that reveals through their attitude to power and to the structural elements of the political system (cultural, ideological, normative and institutional ones).

Keywords: Russian Orthodox Church, power, values, civil society, legal state, liberalism 